\title{
Corrosive effects of nitrate-containing phase change materials used with copper
}

\author{
Vladimír Danielik, Peter Šoška, Katarína Felgerová \\ Slovak University of Technology in Bratislava, Institute of Inorganic Chemistry, Technology and Materials, \\ Radlinského 9, SK - 81237 Bratislava, Slovakia \\ vladimir.danielik@stuba.sk
}

\begin{abstract}
The paper presents the results of a study on the corrosion behaviour of copper (EN CW004A) in five possible phase change materials (PCMs): magnesium nitrate hexahydrate pure and with an addition of $\mathrm{Mg}(\mathrm{OH})_{2}\left(0.5\right.$ wt. \%) or $\mathrm{Sr}(\mathrm{OH})_{2}\left(0.5\right.$ wt. \%) at $90{ }^{\circ} \mathrm{C}$, calcium nitrate tetrahydrate at $50{ }^{\circ} \mathrm{C}$ and a mixture of magnesium nitrate hexahydrate and calcium nitrate tetrahydrate $\left(1: 1\right.$ mass ratio) at $72^{\circ} \mathrm{C}$. The corrosion rate of copper samples is low except for the use of $\mathrm{Mg}\left(\mathrm{NO}_{3}\right)_{2} \cdot 6 \mathrm{H}_{2} \mathrm{O}$ with/without an addition of $\mathrm{Mg}(\mathrm{OH})_{2}$. The lowest corrosion rate was observed for the mixture $\mathrm{Mg}\left(\mathrm{NO}_{3}\right)_{2} \cdot 6 \mathrm{H}_{2} \mathrm{O}-\mathrm{Ca}\left(\mathrm{NO}_{3}\right)_{2} \cdot 4 \mathrm{H}_{2} \mathrm{O}(1: 1)$, and it was ca six times lower than that of pure magnesium nitrate hexahydrate.
\end{abstract}

Keywords: phase change materials, latent heat storage, magnesium nitrate, calcium nitrate, copper, corrosion rate

\section{Introduction}

The lack of fossil fuels and their negative impact on the environment has led to the search of alternative options in recent years. One of such options is the use of solar energy to generate heat. A significant drawback of sunlight use lies in its varying intensity and accumulation of such generated energy. Therefore it is necessary to store the energy obtained. Over the past decades, substances able to store heat in the phase change have been extensively studied. These substances are called phase change materials (PCMs) and their ability to accumulate heat is significantly higher than that of substances utilising sensible heat. An important feature of these compounds is that they accept or deliver heat at a constant temperature. This property has found application in a number of applications where it is necessary to stabilise temperature. PCMs can be widely applied in solar energy utilisation, heat exchangers, building energy-saving, electric peakshaving, textile industry etc. (Sari et al., 2010; Lin et al., 2007; Alvas et al., 2006; Medrano et al., 2009; Mondal 2008).

Suitable thermal, physical and chemical properties are the selection criteria of PCM and they differ considering the type of application. For example, the storage of low potential heat from solar collectors requires PCMs melting at a slightly higher temperature to which tap water is heated (domestic hot water). Important physical properties of PCMs include: (i) phase transition temperature; (ii) sufficiently high phase transition enthalpy; and (iii) the number of phase transition cycles of storage media required for the system. No supercooling and good thermal conductivity are also required. Continuous melting and solidification can lead to the degradation of the PCMs' chemical composition and it is highly desirable that the materials maintain their chemical stability even after long periods of application. PCMs should not react with the construction materials due to process safety and, for the same reason, they should not be flammable, explosive, toxic or otherwise damaging to the environment. Considering an optimal material for the chosen PGM application, all the mentioned properties should be taken into account (Mehling at al., 2008; Sharma et al., 2009).

Salt hydrates are the most important group of PCMs due to their high latent heat of fusion, higher thermal conductivity (Khan et al., 2016) and lower price compared to paraffins (Khudhair et al., 2004). One of the main problems preventing the use of hydrates in heat storage systems is the phase segregation due to incongruent melting caused by the density difference between the formed liquid solution and the dehydrated salt. This results in poor crystallisation and sedimentation of separate components and the reduction of the active volume of heat stored or other serious technical problems in practical applications. Another disadvantage is that salt hydrates may have significant supercooling and corrosive effects on the metallic components of the storage device.

Corrosion of metallic materials in nitrate hydrates has been studied only in a few papers (Cabeza et al., 2001a; Cabeza et al., 2001b; Nagano et al., 2004; Moreno et al., 2014). Cabeza et al. (2001a) tested 
corrosive properties of zinc nitrate hexahydrate upon short term 14 days contact with metals (stainless steel, brass, steel, aluminium, copper). They observed that zinc nitrate hexahydrate is extremely corrosive to brass (Ms58 Flach), steel (1.0345), aluminium (EN AW 2007) and copper (E-Cu 57). Of the mentioned metals, only stainless steel resists the corrosion in zinc nitrate hexahydrate (1.4301). The same results were presented by Cabeza et al. (2001b) for a 75 day contact of the metals with the medium.

Nagano et al. (2004) studied material compatibility of magnesium nitrate hexahydrate with an addition of magnesium chloride hexahydrate (10 \%) and six metals (copper, carbon steel, brass, two types of stainless steel: S30403 and S31603, and aluminium). Each metal sample was placed in a glass tube at a constant temperature of $95^{\circ} \mathrm{C}$ for 90 days. Copper, steel and brass strongly suffered from corrosion with the corrosion weight loss of $106 \mathrm{mg} \mathrm{cm}^{-2} \mathrm{year}^{-1}$, $82 \mathrm{mg} \mathrm{cm}^{-2}$ year $^{-1}$, and $28 \mathrm{mg} \mathrm{cm}^{-2}$ year $^{-1}$, respectively. Stainless steels showed small corrosion weight losses (1.03 mg cm $\mathrm{mear}^{-1}$ and $0.16 \mathrm{mg} \mathrm{cm}^{-2}$ year $^{-1}$ ); however, almost the whole surface of S30403 and a small portion of S31603 were covered with dotted red-brown rust. Corrosion weight loss of aluminium reached the value of $0.04 \mathrm{mg} \mathrm{cm}^{-2}$ year $^{-1}$; aluminium is the only metal that was not corrosively affected by the salt.

Moreno et al. (2014) studied the corrosive properties of several PCMs, zinc nitrate tetrahydrate among them. Four materials were tested: copper, stainless steel 316, carbon steel and aluminium. Each metal was examined after 1, 4 and 12 weeks to determine the corrosion rate, and to examine salt precipitation and bubbles formation. The results showed that the only metal studied compatible with the zinc nitrate tetrahydrate is stainless steel. Copper, aluminium and carbon steel suffered strong corrosion losses after 12 weeks of contact.

As it can be seen, the corrosion behaviour results obtained for selected metals in nitrate hydrates are often contradictory. In this work, corrosion of copper tubes used in heat exchangers was studied in several heat storage media: magnesium nitrate hexahydrate pure and with an addition of $\mathrm{Mg}(\mathrm{OH})_{2}\left(0.5\right.$ wt. \%) or $\mathrm{Sr}(\mathrm{OH})_{2}\left(0.5\right.$ wt. \%) at $90{ }^{\circ} \mathrm{C}$; calcium nitrate tetrahydrate at $50{ }^{\circ} \mathrm{C}$ and a mixture of magnesium nitrate hexahydrate and calcium nitrate tetrahydrate $(1: 1)$ at $72{ }^{\circ} \mathrm{C}$. $\mathrm{Mg}(\mathrm{OH})_{2}$ and $\mathrm{Sr}(\mathrm{OH})_{2}$ were chosen as additives to stabilize the supercooling of magnesium nitrate tetrahydrate (Pilař et al., 2015). Elemental analysis of copper tube composition corresponds to copper EN CW004A.

\section{Experimental}

Two parallel copper tubes (outer diameter: $10.0 \mathrm{~mm}$; inner diameter: $8.2 \mathrm{~mm}$; height: $10 \mathrm{~mm}$ ) were immersed into sealed $400 \mathrm{ml}$ flasks. The flasks were imbedded in a water bath preheated to the chosen temperature: (i) $90{ }^{\circ} \mathrm{C}$ for systems $\mathrm{Mg}\left(\mathrm{NO}_{3}\right)_{2} \cdot 6 \mathrm{H}_{2} \mathrm{O}$; $\mathrm{Mg}\left(\mathrm{NO}_{3}\right)_{2} \cdot 6 \mathrm{H}_{2} \mathrm{O}+0.5 \% \mathrm{Mg}(\mathrm{OH})_{2}$ and $\mathrm{Mg}\left(\mathrm{NO}_{3}\right)_{2}$. . $6 \mathrm{H}_{2} \mathrm{O}+0.5 \% \mathrm{Sr}(\mathrm{OH})_{2}$; (ii) $72{ }^{\circ} \mathrm{C}$ for system $\mathrm{Mg}\left(\mathrm{NO}_{3}\right)_{2} \cdot 6 \mathrm{H}_{2} \mathrm{O}+\mathrm{Ca}\left(\mathrm{NO}_{3}\right)_{2} \cdot 4 \mathrm{H}_{2} \mathrm{O}(1: 1)$; (iii) $50{ }^{\circ} \mathrm{C}$ for system $\mathrm{Ca}\left(\mathrm{NO}_{3}\right)_{2} \cdot 4 \mathrm{H}_{2} \mathrm{O}$. The melting tempera-

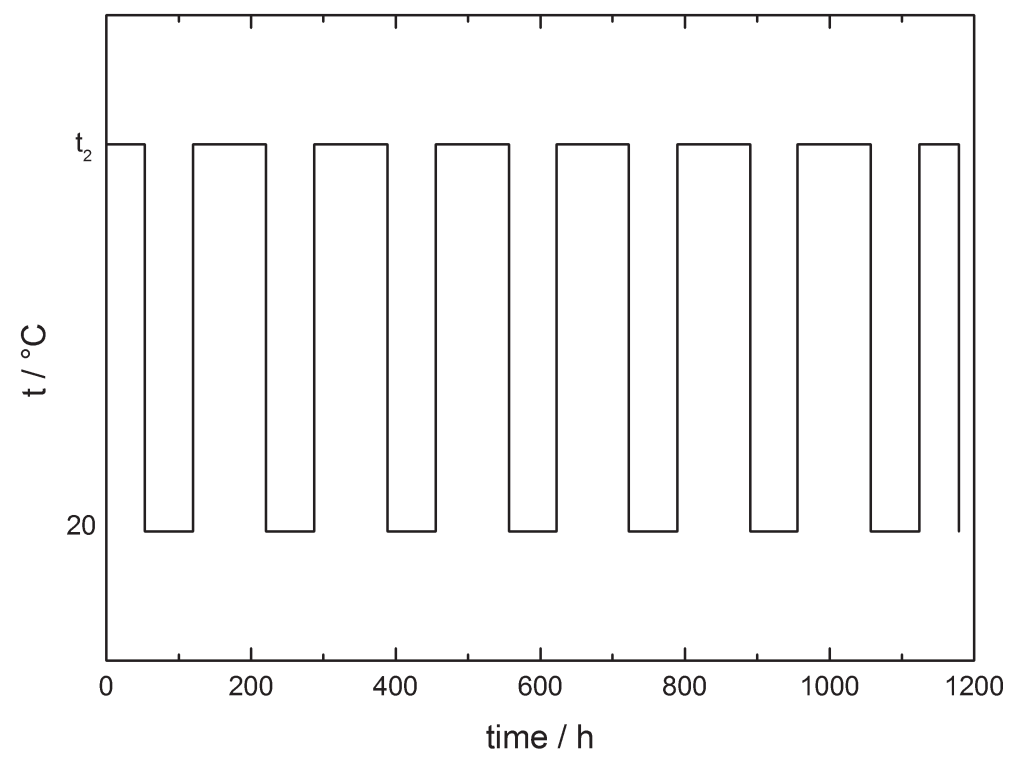

Fig. 1. Temperature regime simulating cooling / heating: $t_{2}$ is the temperature at which corrosion was studied: $90{ }^{\circ} \mathrm{C}$ for $\mathrm{Mg}\left(\mathrm{NO}_{3}\right)_{2} \cdot 6 \mathrm{H}_{2} \mathrm{O} ; \mathrm{Mg}\left(\mathrm{NO}_{3}\right)_{2} \cdot 6 \mathrm{H}_{2} \mathrm{O}+0.5$ wt. $\% \mathrm{Mg}(\mathrm{OH})_{2}$ and $\mathrm{Mg}\left(\mathrm{NO}_{3}\right)_{2} \cdot 6 \mathrm{H}_{2} \mathrm{O}+0.5$ wt. $\% \mathrm{Sr}(\mathrm{OH})_{2} ; 72{ }^{\circ} \mathrm{C}$ for $\mathrm{Mg}\left(\mathrm{NO}_{3}\right)_{2} \cdot 6 \mathrm{H}_{2} \mathrm{O}+\mathrm{Ca}\left(\mathrm{NO}_{3}\right)_{2} \cdot 4 \mathrm{H}_{2} \mathrm{O}(1: 1)$; $50{ }^{\circ} \mathrm{C}$ for $\mathrm{Ca}\left(\mathrm{NO}_{3}\right)_{2} \cdot 4 \mathrm{H}_{2} \mathrm{O}$. 
Tab. 1. Melting temperatures and $\mathrm{pH}$ of liquid phase in studied PCMs.

\begin{tabular}{lll}
\hline PCM & $\mathrm{t} /{ }^{\circ} \mathrm{C}$ & $\mathrm{pH}$ \\
\hline $\mathrm{Mg}\left(\mathrm{NO}_{3}\right)_{2} \cdot 6 \mathrm{H}_{2} \mathrm{O}$ & 88.9 (Cabeza L, Illa J, Roca J, Badia F, Mehling H, Hiebler S, & 6.5 \\
$\mathrm{Mg}\left(\mathrm{NO}_{3}\right)_{2} \cdot 6 \mathrm{H}_{2} \mathrm{O}+0.5$ wt. \% $\mathrm{Mg}(\mathrm{OH})_{2}$ & 88.9 (Khudhair AM, Farid MM (2004)) & 7.0 \\
$\mathrm{Mg}\left(\mathrm{NO}_{3}\right)_{2} \cdot 6 \mathrm{H}_{2} \mathrm{O}+0.5$ wt. \% $\mathrm{Sr}(\mathrm{OH}) 2$ & 88.9 (Khudhair AM, Farid MM (2004)) & 7.5 \\
$\mathrm{Mg}\left(\mathrm{NO}_{3}\right)_{2} \cdot 6 \mathrm{H}_{2} \mathrm{O}+\mathrm{Ca}\left(\mathrm{NO}_{3}\right)_{2} \cdot 4 \mathrm{H}_{2} \mathrm{O}(1: 1)$ & $63.3^{1}$ & 4.5 \\
$\mathrm{Ca}\left(\mathrm{NO}_{3}\right)_{2} \cdot 4 \mathrm{H}_{2} \mathrm{O}$ & 42.7 (Cabeza L, Illa J, Roca J, Badia F, Mehling H, Hiebler S, & 5.0 \\
\hline
\end{tabular}

${ }^{1}$ Temperature of primary crystallisation.

tures and $\mathrm{pH}$ of the liquid phase are summarised in Table 1. During the experiment, the temperature regime simulating cooling / heating was used (Fig. 1). The medium was cooled to $20^{\circ} \mathrm{C}$ in a determined time range, which ensured the solidification of the media. To ensure the solidification of the calcium nitrate tetrahydrate media, an ultrasound device (Tesla, UCA 20613; $20 \mathrm{kHz}$ ) was used. Total time of the experiments was 1179 hours from which the medium was in the liquid state for 664 hours. The weight losses were measured for ca half an hour before the cooling. The copper samples were quickly taken from the flask, flushed with deionised water and dried at $80{ }^{\circ} \mathrm{C}$ for 30 minutes, weighed with the accuracy of $0.00001 \mathrm{~g}$ and returned to the medium.

After the experiment, the samples were treated as described above and analysed by XRD (STOE P, Bruker) and SEM (Carl Zeiss EVO 40, Germany). Then, the corrosion products were removed accord- ing to ISO 8407 using sulphuric acid at $25^{\circ} \mathrm{C}$. The copper samples were immersed in the solution for 3 minutes, flushed with deionised water, dried at $80{ }^{\circ} \mathrm{C}$ for 30 minutes and weighed to obtain the final weight for the total corrosion loss calculation.

\section{Results and discussion}

A visually visible layer of corrosion products was observed in all studied media. XRD records of corrosion products are shown in Fig. 2. The corrosion layer consisted of $\mathrm{Cu}_{2} \mathrm{O}$ in all media, while no $\mathrm{CuO}$ was observed. $\mathrm{Cu}_{2}\left(\mathrm{NO}_{3}\right)(\mathrm{OH})_{3}$ was detected in the corrosion products when magnesium nitrate hexahydrate with/without magnesium hydroxide was used. The presence of this compound in the corrosion products was also indicated when calcium nitrate tetrahydrate was used.

The measured mass losses of the copper samples are presented in Figs. 3 and 4. The weight of the

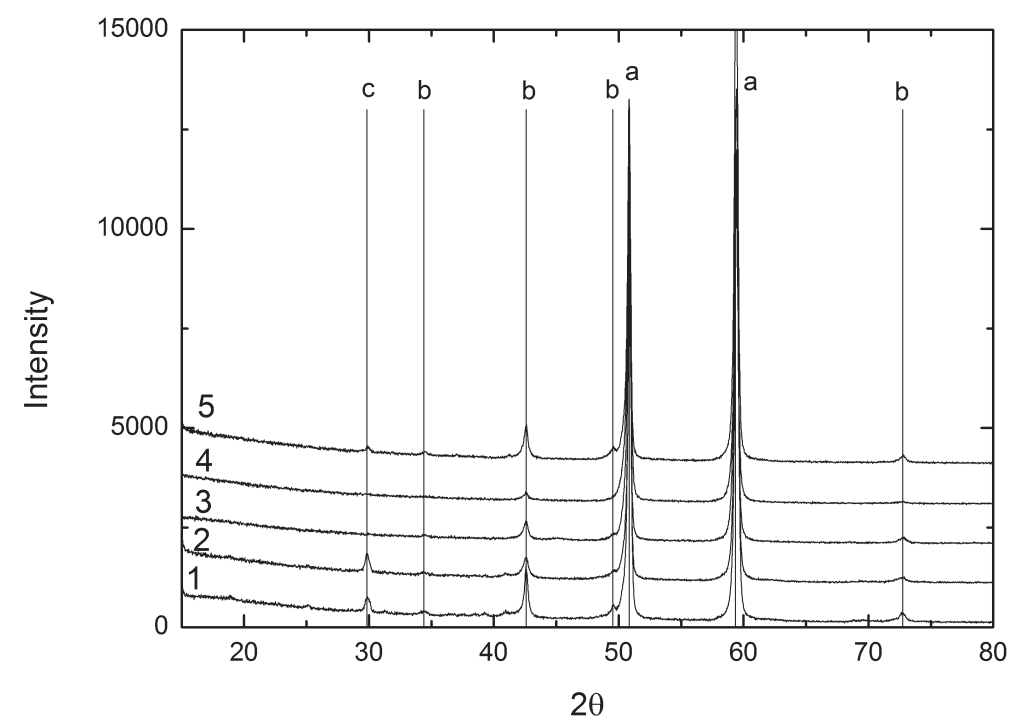

Fig. 2. X-ray diffraction analysis of corrosion products: (a): $\mathrm{Cu}$; (b): $\mathrm{Cu}_{2} \mathrm{O}$; (c): $\mathrm{Cu}_{2}\left(\mathrm{NO}_{3}\right)(\mathrm{OH})_{3}$. (1): $\mathrm{Mg}\left(\mathrm{NO}_{3}\right)_{2} \cdot 6 \mathrm{H}_{2} \mathrm{O}$; (2): $\mathrm{Mg}\left(\mathrm{NO}_{3}\right)_{2} \cdot 6 \mathrm{H}_{2} \mathrm{O}+0.5$ wt. \% $\mathrm{Mg}(\mathrm{OH})_{2}$; (3): $\mathrm{Mg}\left(\mathrm{NO}_{3}\right)_{2} \cdot 6 \mathrm{H}_{2} \mathrm{O}+0.5$ wt. \% $\mathrm{Sr}(\mathrm{OH})_{2} ;(4): \mathrm{Mg}\left(\mathrm{NO}_{3}\right)_{2} \cdot 6 \mathrm{H}_{2} \mathrm{O}+\mathrm{Ca}\left(\mathrm{NO}_{3}\right)_{2} \cdot 4 \mathrm{H}_{2} \mathrm{O}$ (1:1); (5): $\mathrm{Ca}\left(\mathrm{NO}_{3}\right)_{2} \cdot 4 \mathrm{H}_{2} \mathrm{O}$. 


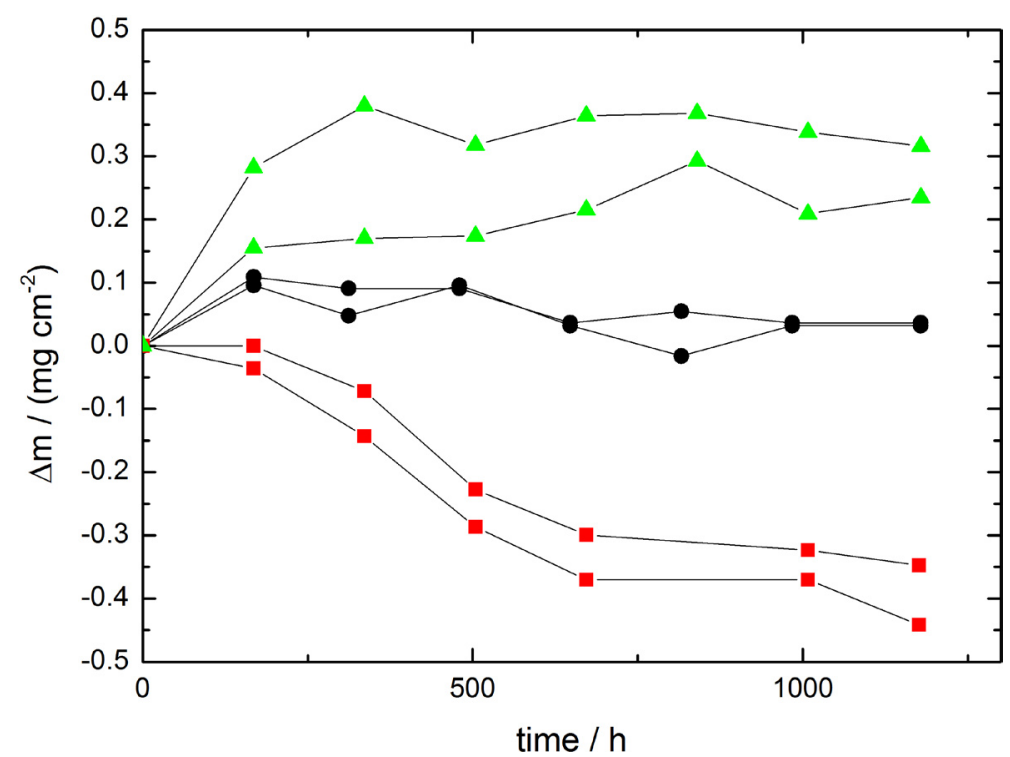

Fig. 3. Mass losses of copper samples during corrosion tests: $(\bullet): \mathrm{Mg}\left(\mathrm{NO}_{3}\right)_{2} \cdot 6 \mathrm{H}_{2} \mathrm{O}$; (匹): $\mathrm{Mg}\left(\mathrm{NO}_{3}\right)_{2} \cdot 6 \mathrm{H}_{2} \mathrm{O}+0.5$ wt. \% Mg(OH $)_{2} ;(\boldsymbol{\Delta}): \mathrm{Mg}\left(\mathrm{NO}_{3}\right)_{2} \cdot 6 \mathrm{H}_{2} \mathrm{O}+0.5$ wt. $\% \mathrm{Sr}(\mathrm{OH})_{2}$.

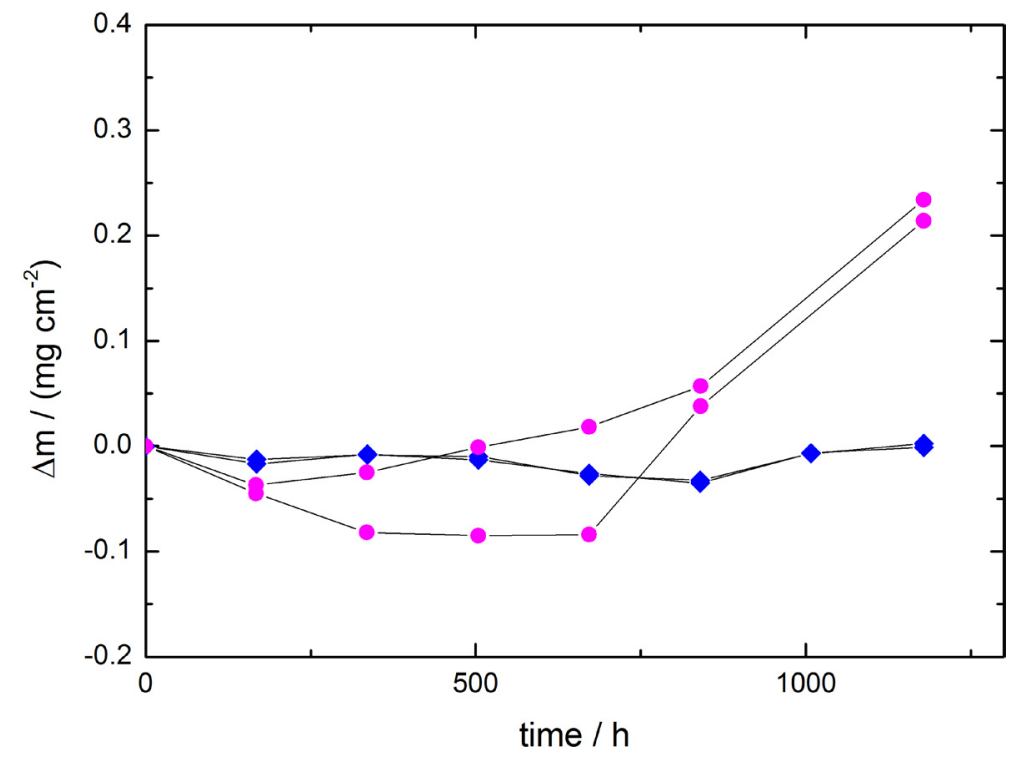

Fig. 4. Mass losses of copper samples during corrosion tests:

$(\diamond): \mathrm{Mg}\left(\mathrm{NO}_{3}\right)_{2} \cdot 6 \mathrm{H}_{2} \mathrm{O}+\mathrm{Ca}\left(\mathrm{NO}_{3}\right)_{2} \cdot 4 \mathrm{H}_{2} \mathrm{O}(1: 1) ;(\bullet): \mathrm{Ca}\left(\mathrm{NO}_{3}\right)_{2} \cdot 4 \mathrm{H}_{2} \mathrm{O}$.

copper samples in the $\mathrm{Mg}\left(\mathrm{NO}_{3}\right)_{2}$ medium slightly increased at the beginning of the test and then remained approximately constant (Fig. 3). When magnesium hydroxide was added to the PGM, the weight of the sample markedly decreased during the first 700 hours of the corrosion test and then remained approximately constant. On the other hand, when strontium hydroxide was added, the weight of the sample markedly increased during the first 300 hours of the corrosion test and then remained approximately constant. Such behaviour is visible also on the surface of the samples (Fig. 5a-5c). Morphology of the corrosion layer in magnesium nitrate hexahydrate with/without magnesium hydroxide is typical for a layer in which corrosion products are partially dissolved in the medium (Fig. $5 \mathrm{a}, 5 \mathrm{~b})$. When strontium hydroxide was added, the layer was more compact. Differences in the morphology of the corrosion products layer are more visible in Fig. 6. In case of $\mathrm{Sr}(\mathrm{OH})_{2}$, a compact layer can be seen (Fig. 6c). Formation of the corrosion product $\mathrm{Cu}_{2}\left(\mathrm{NO}_{3}\right)(\mathrm{OH})_{3}$ observed by XRD (Fig. 2) can explain these differences. Cross-sections of the corrosion layer are shown in Fig. 7. Surface of the copper substrate was rough and the corrosion layer was visible in the $\mathrm{Mg}\left(\mathrm{NO}_{3}\right)_{2}$ medium (Fig. 7a). The 


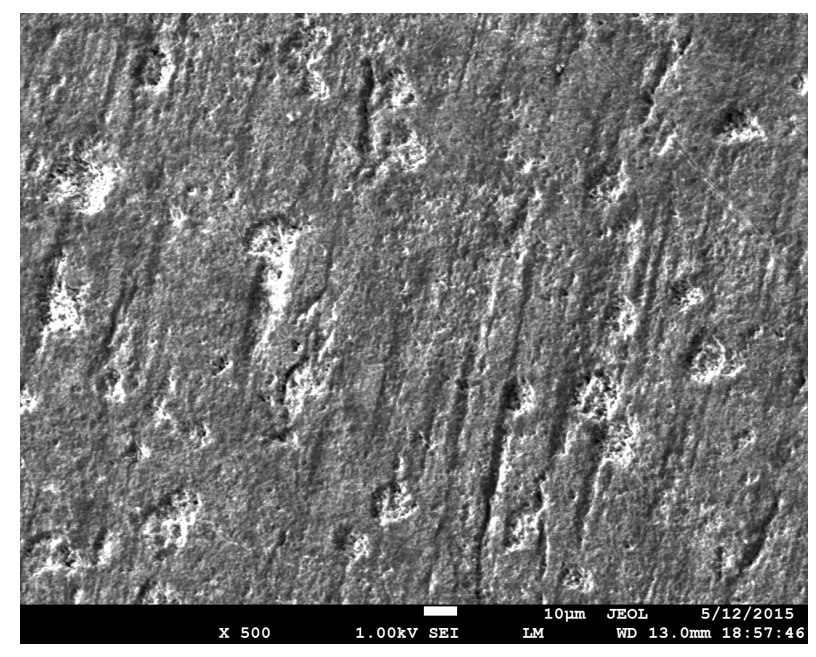

(a)

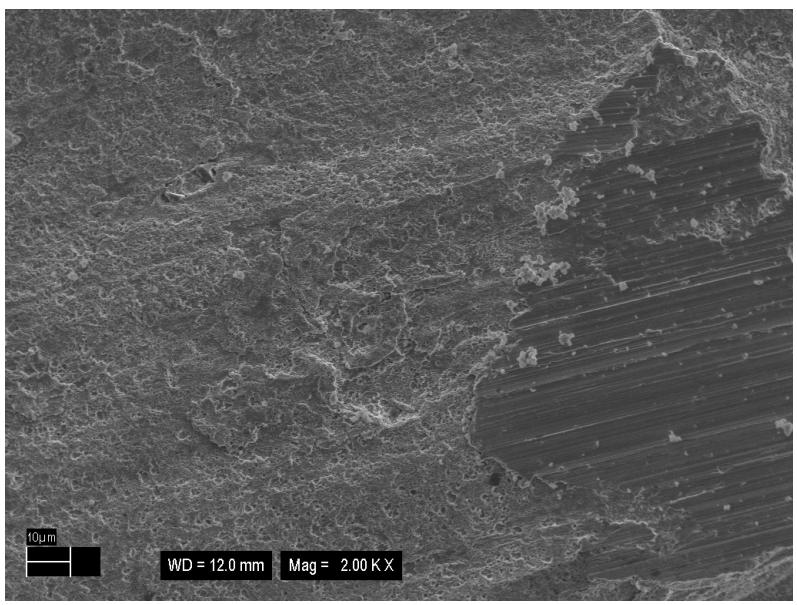

(c)

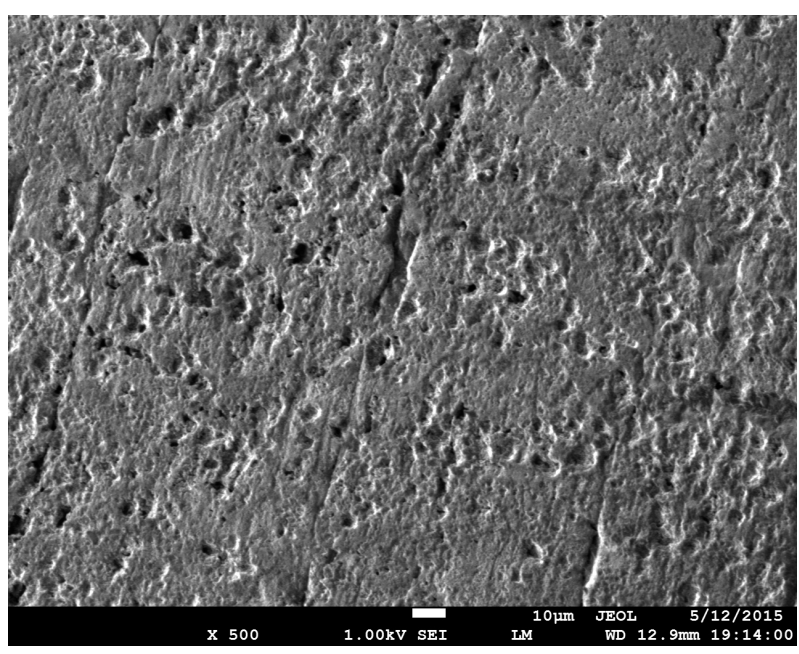

(b)

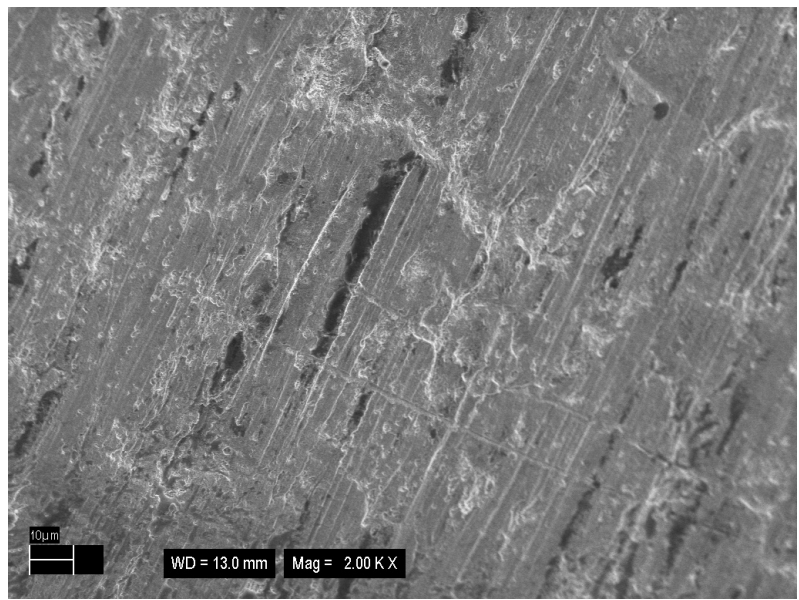

(d)

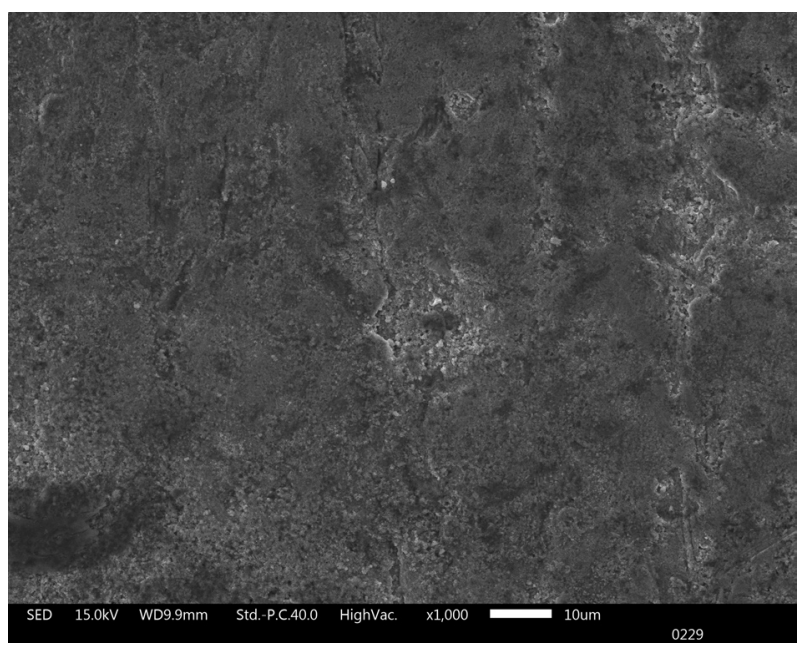

(e)

Fig. 5. SEM records of the copper samples surface after corrosion tests: (a): $\mathrm{Mg}\left(\mathrm{NO}_{3}\right)_{2} \cdot 6 \mathrm{H}_{2} \mathrm{O}$; (b): $\mathrm{Mg}\left(\mathrm{NO}_{3}\right)_{2} \cdot 6 \mathrm{H}_{2} \mathrm{O}+0.5$ wt. $\% \mathrm{Mg}(\mathrm{OH})_{2} ;$ (c): $\mathrm{Mg}\left(\mathrm{NO}_{3}\right)_{2} \cdot 6 \mathrm{H}_{2} \mathrm{O}+0.5$ wt. $\% \mathrm{Sr}(\mathrm{OH})_{2}$; (d): $\mathrm{Mg}\left(\mathrm{NO}_{3}\right)_{2} \cdot 6 \mathrm{H}_{2} \mathrm{O}+\mathrm{Ca}\left(\mathrm{NO}_{3}\right)_{2} \cdot 4 \mathrm{H}_{2} \mathrm{O}(1: 1) ;(\mathrm{e}): \mathrm{Ca}\left(\mathrm{NO}_{3}\right)_{2} \cdot 4 \mathrm{H}_{2} \mathrm{O}$. 


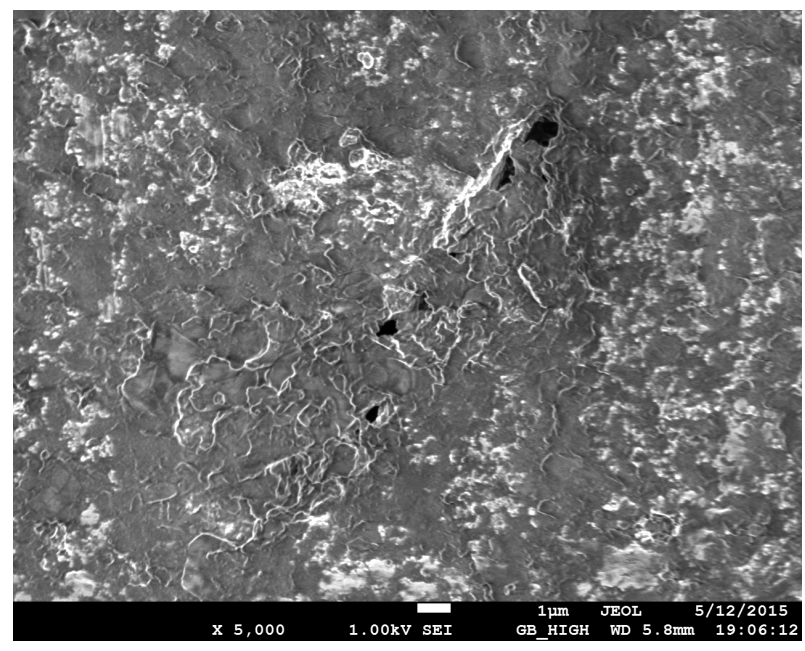

(a)

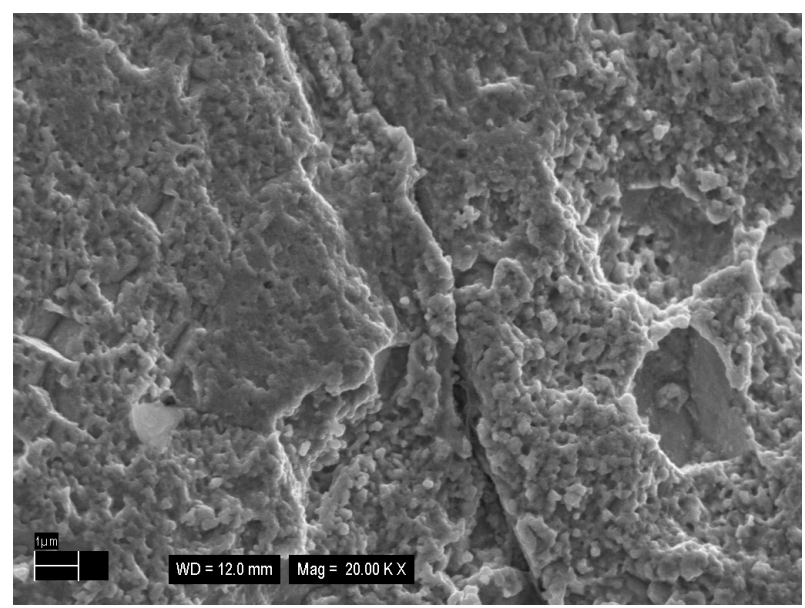

(c)

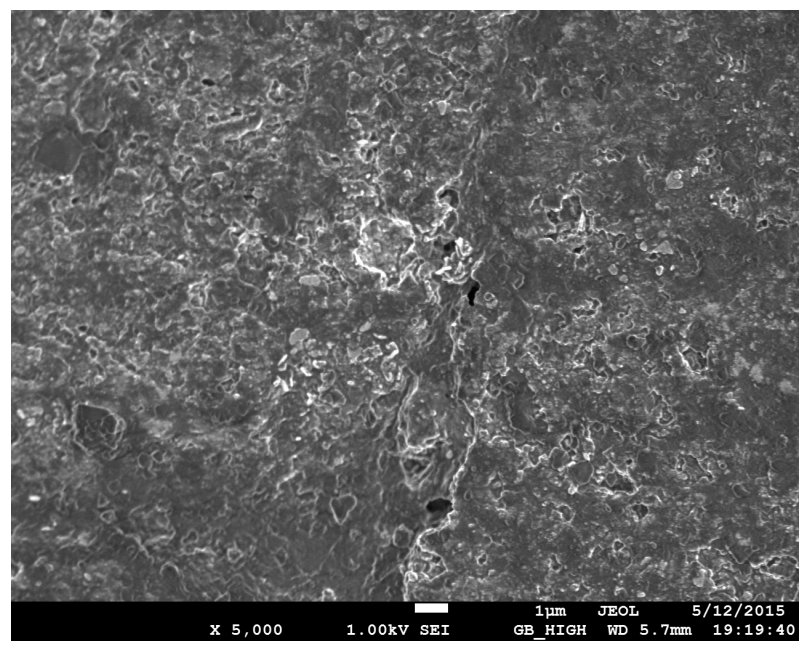

(b)

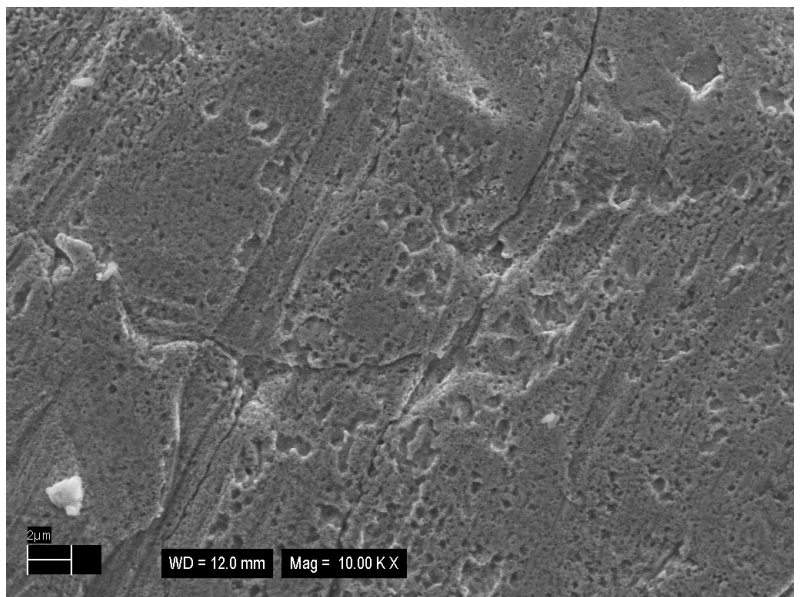

(d)

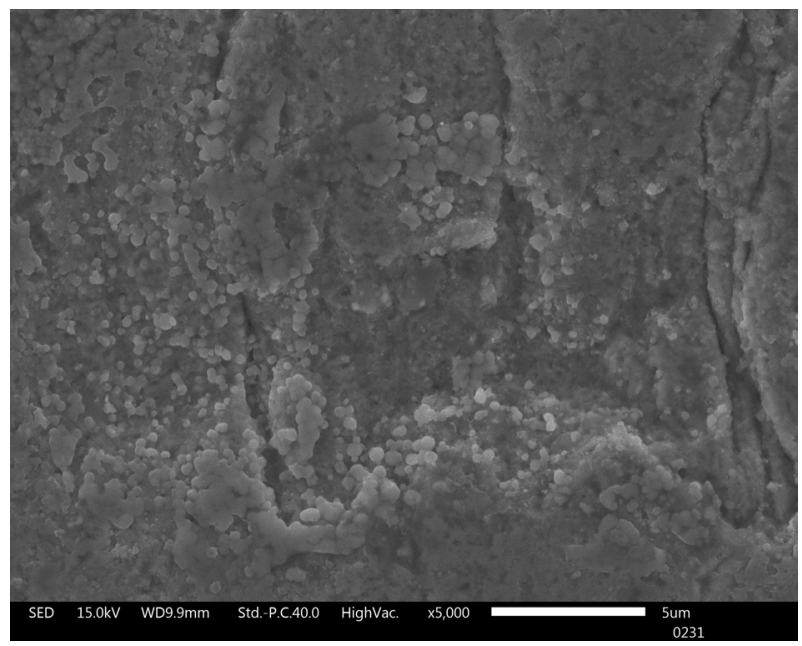

(e)

Fig. 6. Detailed SEM records of the copper samples surface after corrosion tests: (a): $\mathrm{Mg}\left(\mathrm{NO}_{3}\right)_{2} \cdot 6 \mathrm{H}_{2} \mathrm{O}$;

(b): $\mathrm{Mg}\left(\mathrm{NO}_{3}\right)_{2} \cdot 6 \mathrm{H}_{2} \mathrm{O}+0.5$ wt. \% $\mathrm{Mg}(\mathrm{OH})_{2} ;(\mathrm{c}): \mathrm{Mg}\left(\mathrm{NO}_{3}\right)_{2} \cdot 6 \mathrm{H}_{2} \mathrm{O}+0.5$ wt. $\% \mathrm{Sr}(\mathrm{OH})_{2}$; (d): $\mathrm{Mg}\left(\mathrm{NO}_{3}\right)_{2} \cdot 6 \mathrm{H}_{2} \mathrm{O}+\mathrm{Ca}\left(\mathrm{NO}_{3}\right)_{2} \cdot 4 \mathrm{H}_{2} \mathrm{O}(1: 1) ;(\mathrm{e}): \mathrm{Ca}\left(\mathrm{NO}_{3}\right)_{2} \cdot 4 \mathrm{H}_{2} \mathrm{O}$. 


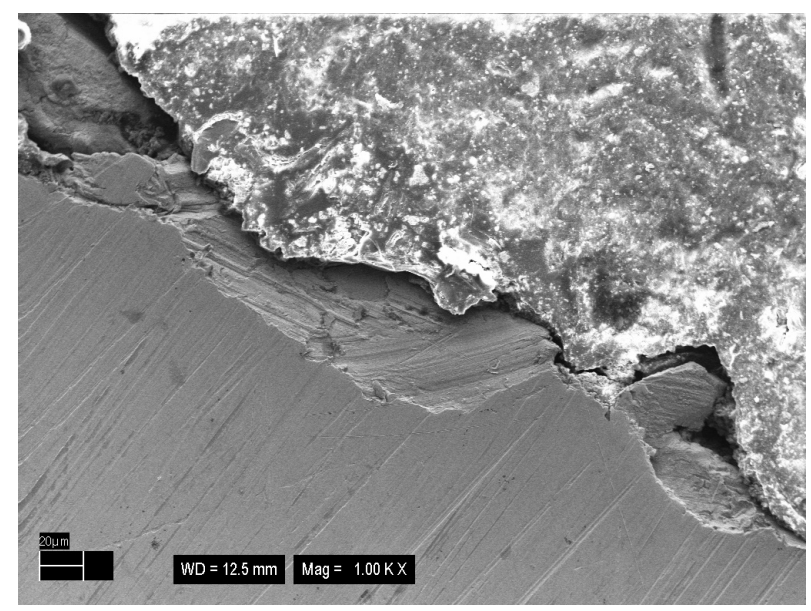

(a)

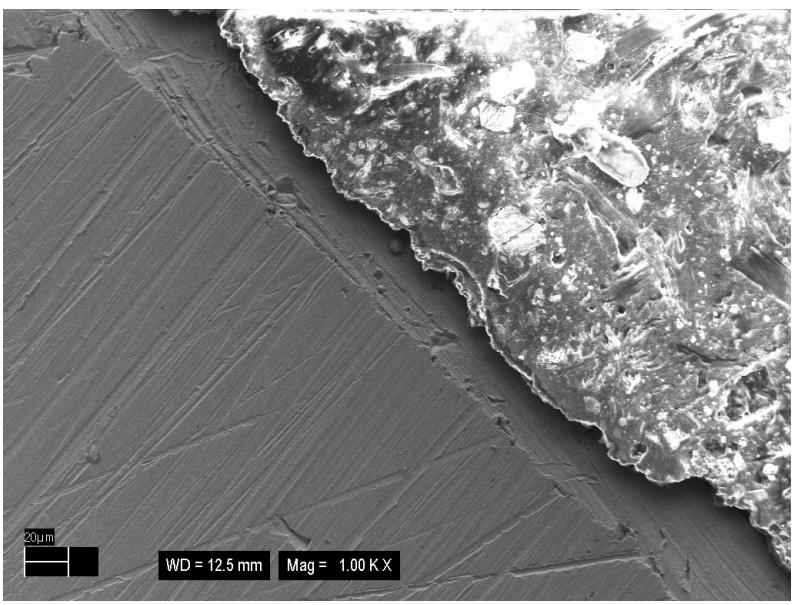

(c)

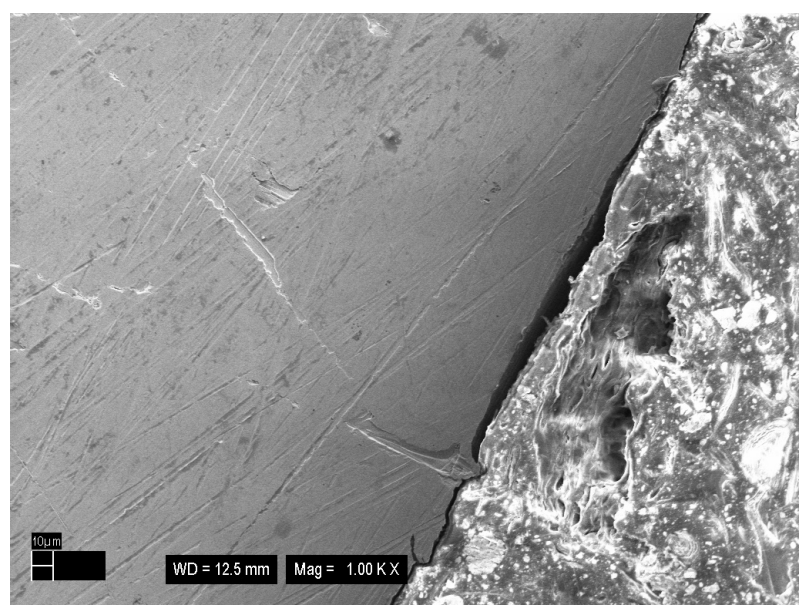

(b)

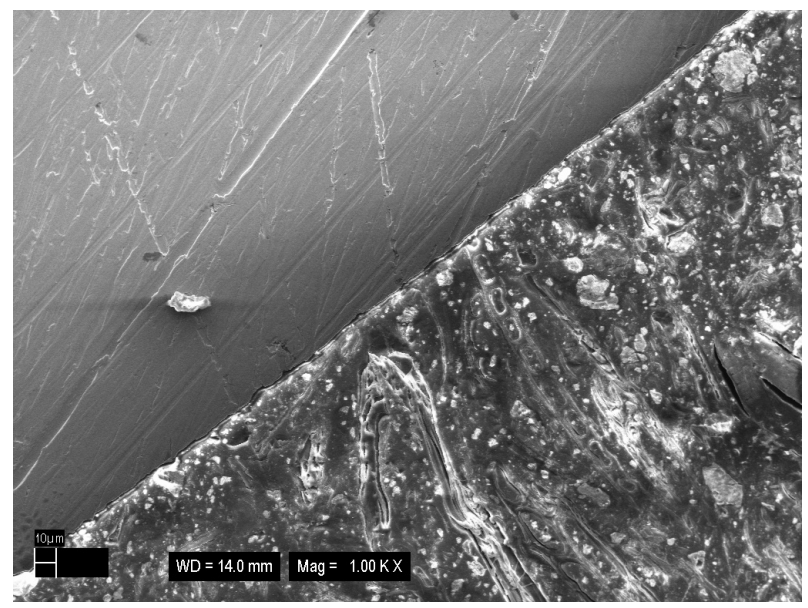

(d)

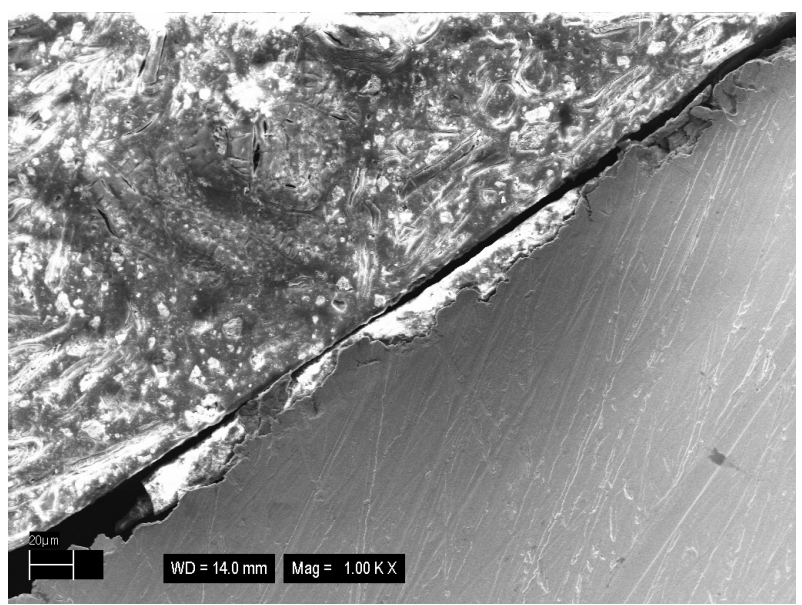

(e)

Fig. 7. SEM records of the cross-section of copper samples after corrosion tests: (a): $\mathrm{Mg}\left(\mathrm{NO}_{3}\right)_{2} \cdot 6 \mathrm{H}_{2} \mathrm{O}$;

(b): $\mathrm{Mg}\left(\mathrm{NO}_{3}\right)_{2} \cdot 6 \mathrm{H}_{2} \mathrm{O}+0.5$ wt. $\% \mathrm{Mg}(\mathrm{OH})_{2} ;(\mathrm{c}): \mathrm{Mg}\left(\mathrm{NO}_{3}\right)_{2} \cdot 6 \mathrm{H}_{2} \mathrm{O}+0.5$ wt. \% $\mathrm{Sr}(\mathrm{OH})_{2}$; (d): $\mathrm{Mg}\left(\mathrm{NO}_{3}\right)_{2} \cdot 6 \mathrm{H}_{2} \mathrm{O}+\mathrm{Ca}\left(\mathrm{NO}_{3}\right)_{2} \cdot 4 \mathrm{H}_{2} \mathrm{O}(1: 1) ;(\mathrm{e}): \mathrm{Ca}\left(\mathrm{NO}_{3}\right)_{2} \cdot 4 \mathrm{H}_{2} \mathrm{O}$. 
layer was ca $40 \mu \mathrm{m}$ thick and cracked. Surprisingly, when $\mathrm{Mg}(\mathrm{OH})_{2}$ was added to the PCM, no corrosion layer was visible (Fig. 7b), which is in contradiction to the SEM observations of the surface and XRD of the corrosion products. When $\mathrm{Sr}(\mathrm{OH})_{2}$ was added to the medium, a ca $30 \mu \mathrm{m}$ thick homogenous corrosion products layer was formed on the surface of the sample (Fig 7c). Based on the SEM observations of the surface and the cross-section of the copper sample, it can be concluded that the layer is compact and forms a barrier preventing the contact with the solution, which is in agreement with calculated corrosion rates (Table 2 ).

The weight of the copper samples in the mixture of $\mathrm{Mg}\left(\mathrm{NO}_{3}\right)_{2}-\mathrm{Ca}\left(\mathrm{NO}_{3}\right)_{2}$ remained approximately constant during the corrosion test. It seems that no layer of the corrosion products is formed in the $\mathrm{Mg}\left(\mathrm{NO}_{3}\right)_{2}-\mathrm{Ca}\left(\mathrm{NO}_{3}\right)_{2}$ medium (Fig. 5d). However, a closer examination of the sample surface revealed that a thin compact layer was formed (Fig. 6d), which did not cover the whole surface of the sample as it follows from Fig. 7d. The surface of the copper substrate was smooth without any significant corrosion layer, which is in accordance with the calculated corrosion rate (Table 2).

When pure calcium nitrate tetrahydrate was used as the PCM, the weight of the sample decreased during the first 300 hours of the corrosion test and then markedly increased (Fig. 4). A non-compact layer of corrosion products was formed on the surface of the copper substrate (Figs. 5e, 6e). From the crosssection it can be seen that the loss of material affects the surface to the depth of $20 \mu \mathrm{m}$ (Fig. 7e).

After the corrosion tests, corrosion products were removed according to ISO 8407 and the corrosion rate was calculated considering the time the sample spent in the molten medium. The results obtained are presented in Table 2 . It can be seen that the corrosion rate of copper is quite high in the magnesium nitrate hexahydrate with/without an addition of $\mathrm{Mg}(\mathrm{OH})_{2}$. When using mixture $\mathrm{Mg}\left(\mathrm{NO}_{3}\right)_{2} \cdot 6 \mathrm{H}_{2} \mathrm{O}-$ $\mathrm{Ca}\left(\mathrm{NO}_{3}\right)_{2} \cdot 4 \mathrm{H}_{2} \mathrm{O}(1: 1)$, the corrosion rate was ca six times lower. It seems that the corrosion of copper is more inhibited in this mixture and copper can be used as a construction material for long term applications using this mixture. The corrosion rate in calcium nitrate tetrahydrate is about two times lower than in the magnesium nitrate hexahydrate. The behaviour of copper in both cases is different and it should be noted that $\mathrm{pH}$ values of the liquid phases differ.

A guide for corrosion weight loss used in the industry can be found in literature (Moreno et al., 2014; Cabeza et al., 2003; Davis 2000), it follows that copper EN CW004A can be used for long term applications. However, the corrosion rate of copper in magnesium nitrate hexahydrate with/without an addition of magnesium hydroxide is close to the value of $10 \mathrm{mg} \mathrm{cm}^{-2}$ year $^{-1}$, at such a value caution for long term applications is recommended. Nagano et al. (2004) showed that strong copper corrosion in magnesium nitrate hexahydrate with the addition of magnesium chloride hexahydrate (10\%). The corrosion rate presented in this work is significantly lower; however, no chlorides were present in the studied PCMs.

\section{Conclusions}

In this study, corrosion of copper EN CW004A was studied in the following assumed PCMs: magnesium nitrate hexahydrate pure and with an addition of $\mathrm{Mg}(\mathrm{OH})_{2}\left(0.5\right.$ wt. \%) or $\operatorname{Sr}(\mathrm{OH})_{2}\left(0.5\right.$ wt. \%) at $90{ }^{\circ} \mathrm{C}$; calcium nitrate tetrahydrate at $50{ }^{\circ} \mathrm{C}$ and a mixture of magnesium nitrate hexahydrate and calcium nitrate tetrahydrate $(1: 1)$ at $72{ }^{\circ} \mathrm{C}$. $\mathrm{Mg}(\mathrm{OH})_{2}$ and $\mathrm{Sr}(\mathrm{OH})_{2}$ were chosen as additives stabilising the supercooling of magnesium nitrate tetrahydrate (Pilař et al., 2015). From the corrosion tests results follows that the corrosion rate is the lowest when mixture $\mathrm{Mg}\left(\mathrm{NO}_{3}\right)_{2} \cdot 6 \mathrm{H}_{2} \mathrm{O}-\mathrm{Ca}\left(\mathrm{NO}_{3}\right)_{2} \cdot 4 \mathrm{H}_{2} \mathrm{O}(1: 1)$ was used. Copper can be used for long term applications in this mixture. When magnesium nitrate hexahydrate pure and with an addition of $\mathrm{Mg}(\mathrm{OH})_{2}(0.5$ wt. \%) were used as the PCM, caution concerning long term applications is recommended.

\section{Acknowledgement}

This work was supported by courtesy of the Slovak Grant Agency (VEGA 1/0101/14).

Tab. 2. Corrosion rate of pure copper samples (EN CW004A) in studied PCMs.

\begin{tabular}{lc}
\hline PCM & Corrosion rate $/\left(\mathrm{mg} \mathrm{cm}^{-2}\right.$ year $\left.^{-1}\right)$ \\
\hline $\mathrm{Mg}\left(\mathrm{NO}_{3}\right)_{2} \cdot 6 \mathrm{H}_{2} \mathrm{O}$ & 8.6 \\
$\mathrm{Mg}\left(\mathrm{NO}_{3}\right)_{2} \cdot 6 \mathrm{H}_{2} \mathrm{O}+0.5$ wt. $\% \mathrm{Mg}(\mathrm{OH})_{2}$ & 8.9 \\
$\mathrm{Mg}\left(\mathrm{NO}_{3}\right)_{2} \cdot 6 \mathrm{H}_{2} \mathrm{O}+0.5$ wt. $\% \mathrm{Sr}(\mathrm{OH})_{2}$ & 5.4 \\
$\mathrm{Mg}\left(\mathrm{NO}_{3}\right)_{2} \cdot 6 \mathrm{H}_{2} \mathrm{O}+\mathrm{Ca}\left(\mathrm{NO}_{3}\right)_{2} \cdot 4 \mathrm{H}_{2} \mathrm{O}(1: 1)$ & 1.5 \\
$\mathrm{Ca}\left(\mathrm{NO}_{3}\right)_{2} \cdot 4 \mathrm{H}_{2} \mathrm{O}$ & 5.4 \\
\hline
\end{tabular}




\section{References}

Alvas LH, Gonzalez JE, Dukhan N (2006) Initial Analysis of PCM Integrated Solar Collectors. Journal of Solar Energy Engineering 128: 173-177. doi: $10.1115 / 1.2188532$.

Cabeza L, Illa J, Roca J, Badia F, Mehling H, Hiebler S, Ziegler F (2001a) Immersion corrosion tests on metalsalt hydrate pairs used for latent heat storage in the 32 to 36 Deg temperature range. Mater Corros 52: 140-146. doi: 10.1002/1521-4176(200102)52:2<140::AID-MACO 140>3.0.CO;2-R.

Cabeza L, Illa J, Roca J, Badia F, Mehling H, Hiebler S, Ziegler F (2001b) Middle term immersion corrosion tests on metal-salt hydrate pairs used for latent heat storage in the 32 to 36 Deg temperature range. Mater Corros 52: 748-754. doi: 10.1002/1521-4176 (200110)52:10<748::AID-MACO748>3.0.CO;2-S.

Cabeza LF, Svensson G, Hiebler S, Mehling H (2003) Thermal performance of sodium acetate trihydrate thickened with different materials as phase change energy storage material. Appl Therm Eng 23: 1697-1704. doi: 10.1016/S1359-4311(03)00107-8.

Davis JR (2000) Corrosion - understanding the basics. 1st ed., ASM International, Ohio; ISBN: 978-0-87170641-6 cited by Moreno P, Miró L, Solé A, Barreneche C, Solé C, Martorell I, Cabeza LF (2014).

Khan Z, Khan Z, Ghafoor A (2016) A review of performance enhancement of PCM based latent heat storage system within the context of materials, thermal stability and compatibility. Energy Convers. Manage 115: 132-158. doi: 10.1016/j.enconman. 2016.02.045.

Khudhair AM, Farid MM (2004) A review on energy conservation in building applications with thermal storage by latent heat using phase change materials. Energy Convers Manage 45: 263-275. doi: 10.1016/ S0196-8904(03)00131-6.

Lin KP, Di HF (2007) Performance of a hybrid heating system with thermal storage using shape-stabilized phase-change material plates. Applied Energy 84: 1068-1077. doi: 10.1016/j.apenergy.2006.09.015.
Medrano M, Yilmaz MO, Nogués M, Martorell I, Roca J, Cabeza LF (2009) Experimental evaluation of commercial heat exchangers for use as PCM thermal storage systems. Applied Energy 86: 2047-2055. doi: 10.1016/j.apenergy.2009.01.014.

Mehling H, Cabeza LF (2008) Heat and cold storage with PCM an up to date introduction into basics and applications. Springer, Berlin. ISBN 978-3-54068557-9.

Mondal S (2008) Phase change materials for smart textiles - An overview. Applied Thermal Engineering 28: 1536-1550. doi: 10.1016/j.applthermaleng.2007. 08.009.

Moreno P, Miró L, Solé A, Barreneche C, Solé C, Martorell I, Cabeza LF (2014) Corrosion of metal and metal alloy containers in contact with phase change materials (PCM) for potential heating and cooling applications. Appl Energy 125: 238-245. doi: 10.1016/j.apenergy.2014.03.022.

Nagano K, Ogawa K, Mochida T, Hayashi K, Ogoshi H (2004) Performance of heat charge/discharge of magnesium nitrate hexahydrate and magnesium chloride hexahydrate mixture to a single vertical tube for a latent heat storage system. Appl Therm Eng 24: 209-220. doi: 10.1016/j.applthermaleng.2003.09. 002.

Pilař R, Sádovská G, Honcová P (2015) Thermal capacity and accumulation properties of $\mathrm{Ca}\left(\mathrm{NO}_{3}\right)_{2} \cdot 4 \mathrm{H}_{2} \mathrm{O}$ and $\mathrm{Mg}\left(\mathrm{NO}_{3}\right)_{2} \cdot 6 \mathrm{H}_{2} \mathrm{O}$ (in Czech). In: Proceedings of Termoanalytický seminář TAS 2015, University Pardubice, Czech Republic pp. 29-34. ISBN 978-807395-888-6.

Sari A, Biçer A, Karaipekli A, Alkan C, Karadag A (2010) Synthesis, thermal energy storage properties and thermal reliability of some fatty acid esters with glycerol as novel solid-liquid phase change materials. Solar Energy Materials and Solar Cells 94: 1711-1715. doi: 10.1016/j.solmat.2010.05.033.

Sharma A, Tyagi VV , Chen CR, Buddhi D (2009) Review on thermal energy storage with phase change materials and applications. Renewable and Sustainable Energy Reviews 13: 318-345. doi: 10.1016/j.rser.2007.10.005. 